\title{
Nitrogen losses in ruminant manure management and use of cattle manure vermicast to improve forage quality
}

\author{
Aminu Nasiru • Mahamad Hakimi Ibrahim • \\ Norli Ismail
}

Received: 14 March 2013/Accepted: 11 December 2013/Published online: 4 April 2014

(C) The Author(s) 2014. This article is published with open access at Springerlink.com

\begin{abstract}
Ruminants have low efficiency of nitrogen utilisation; unutilised nitrogen is being excreted in the faeces and urine. The most effective way to minimise nitrogen losses in ruminant production is through efficient feeding strategy. Ruminant manure is an inevitable consequence of its production. All these have adverse environmental effects. Composting and vermicomposting have been suggested as efficient tools for recycling manure, these bring a stabilised and sanitised end product for agriculture. Composting process is an accelerated aerobic degradation of fresh organic matter by microorganism to mature compost. Nevertheless, it may bring some environmental problems by releasing gases which include ammonia, methane and nitrous oxide, reduce the agronomic value of the manure and increase the cost of composting through turning of the compost to ensure aeration. To overcome the cost of composting and produce high quality products, vermicomposting is being recommended. Vermicomposting involves the bio-oxidation and stabilisation of organic material by the joint action of earthworm and microorganism. Moreover, the combination of composting and vermicomposting has been considered as a way of achieving stabilised substrates. Ensiled cattle manure treated with straws has been used to improve nutritional quality of ruminant feed and the result was encouraging.
\end{abstract}

\footnotetext{
A. Nasiru ( $₫) \cdot$ M. H. Ibrahim · N. Ismail

Environmental Technology Division, School of Industrial Technology, Universiti Sains Malaysia (USM), Pulau Pinang, Malaysia

e-mail: nasirua4601@buk.edu.ng

M. H. Ibrahim

e-mail: mhakimi@usm.my

N. Ismail

e-mail: norlii@usm.my
}

Vermicast, an end product of vermicomposting has higher nutrients content compared with manure or composted manure. Therefore vermicomposting of ruminant manure with rice/wheat straws might have the potential of being used as feed supplement to small ruminant. The likely benefit will be an increase in feed intake, increase in microbial protein supply, increase in fibre digestibility and possibly an increase in weight gain. The aim of this review is to discuss nitrogen losses in ruminant production and manure management and to provide an insight on the possibility of using vermicast as feed supplement to ruminants and as probiotic for treating fibrous feed.

Keywords Composting $\cdot$ Feed supplement $\cdot$ Nitrogen loss · Ruminant manure · Vermicast

\section{Introduction}

According to O'mara (2011) Animal agriculture contributes $8-10 \%$ of global greenhouse emission. This is dominated by emissions from ruminants. According to Tamminga (2003) a number of soluble and gaseous compounds directly or indirectly originating from animal production are known to have a negative effect on the environment. Animal metabolism and faecal excretion are responsible for direct emissions (Dijkstra et al. 2011a; Tamminga 1992). Methane and Nitrous Oxide emissions are an environmental concern because of their global warming potentials are 25 and 298 times than that of $\mathrm{CO}_{2}$ respectively (IPCC 2007). Undigested and unutilized nutrients are excreted into the environment in the form of faeces and urine together with fermentation and respiration gases (Dijkstra et al. 2011b; Hristov and Jouany 2005; Tamminga 1992). Nutrient losses from animal 
production are inevitable, excessive animal waste are mainly from an intensive ruminant production (management), high stocking density, and or from feeding nutrients more than required by the animal (Tamminga 1992). Proper utilisation of manure is required to achieve long term sustainability in livestock production. This can be achieved through composting (Hao et al. 2001, 2004), vermicomposting (Loh et al. 2005; Gutiérrez-Miceli et al. 2008) and biogas production (Amon et al. 2007; Massé et al. 2011).

In developing countries, livestock depends on fibrous crop residues, these have low digestibility, low protein content, poor palatability and bulkiness (Zadrazil et al. 1995). To enhance animal's performance, the nutritional quality and palatability of fibrous crop residues have to be improved. This can be achieved by manipulating ruminal fermentation. For decades efforts have been put to produce ingredients for animal feedstuff from manure. The aim of this review is to discuss the various stages of Nitrogen losses in ruminant production, manure management and the potential of using vermicomposting product (vermicast) as feed supplement, probiotic and mean of feed treatment to ruminants.

\section{Nitrogen losses in ruminants}

Livestock has low efficiency of Nitrogen utilisation, it ranges from 5 to $45 \%$ depending on animal type, system and management (Oenema 2006). Nutrients profile in the feed, chemical and or biological treatment have direct effect on animal productivity as well as faecal (van Vliet et al. 2007) and urine output, these depends on how the nutrients involved are utilised. van der Stelt et al. (2008) found that reducing dietary crude protein level by $25 \%$ of $200 \mathrm{~g} / \mathrm{kg}$ of dry matter result in 21 and $66 \%$ decrease of N-losses in faeces and urine respectively, while on the other hand $75 \%$ increase of $108 \mathrm{~g} / \mathrm{kg}$ crude protein led to $56 \%$ increase in total Nitrogen loss in the slurries. In another different experiment with protein-binding polyphenol compound Powell et al. (2009), reported that tannins decreases urinary Nitrogen lost and increases the faecal Nitrogen lost in cattle. This is also applies to small ruminant (Waghorn 2008). Dietary tannins are known to reduce the rate and extent of protein degradation in the rumen and increase metabolic faecal Nitrogen loss (Patra and Saxena 2011). The sources of ruminants faecal Nitrogen are endogenous losses and indigestible excretion from the intestines. In addition to faecal sources, ammonia lost from the rumen in form of urea form the sources of ruminants urinary Nitrogen. Another source of N-losses is from inefficient utilisation of absorbed protein for maintenance and for synthesis of milk and body protein (Tamminga 1992).

\section{Ruminant manure nitrogen lost during storage}

Ruminant manure from animal houses is a mixture of faeces and urine together with bedding materials, spilt feed and drinking water, and water used for washing. Slurries is collected from below slatted floors and have lower dry matter content than other manures, this is due to addition of washing water and little use of bedding materials. In housing systems where livestock are tied, the excretion is separated into solid manure (farmyard manure; FYM), mainly containing faeces and straw, and liquid manure, which is a mixture of water, urine and dissolvable faecal components (Sommer and Hutchings 2001). Ruminant manure is a valuable resource as a soil fertiliser providing both macro and micro nutrients required for the plant growth and is a low-cost alternative to mineral fertiliser (Lazcano et al. 2008). This enhances both livestock and crop production (Powell et al. 1999). Traditionally ruminant manure is normally spread in the farm without any treatment. When applied in excess to the land requirement can lead to environmental pollution. These include over fertilisation of soil, soil toxicity, dispersal of pathogens and weed seeds, odour, water pollution, and increase in greenhouse gas emission and may present health risk (Dominguez and Edwards 2011). Another problem with manure is its bulkiness as it contains a lot of moisture content making it difficult to haul to a distance place (Larney and Hao 2007). Manure characteristics are functions of farm management, animal diet and facilities (Mathot et al. 2012); Table 1.

In most countries livestock manure are stored for a month or more before applied into the soil (Sommer and Hutchings 2001). On the other hand, manure storage contributes to the atmospheric pool of gases such as ammonia, nitrous oxide and methane (Kulling et al. 2001). The degree of gas emissions depends on feed digestibility and general animal performance (Mathot et al. 2012). Due to

Table 1 Composition of cattle manure $\left(\mathrm{gKg}^{-1} \mathrm{DM}\right)$

\begin{tabular}{|c|c|c|c|c|c|c|c|}
\hline $\mathrm{DM}$ & $\mathrm{CP}$ & $\mathrm{NDF}$ & $\mathrm{ADF}$ & Ash & TK & $\mathrm{TP}$ & Author \\
\hline 176 & 93.8 & NA & NA & NA & 7.0 & 3.0 & $\begin{array}{l}\text { Alvarez and Liden } \\
\text { (2009) }\end{array}$ \\
\hline 440 & 33.1 & NA & NA & NA & 4.8 & 3.3 & Garg et al. (2006) \\
\hline 200 & 82.1 & 472.1 & 395.4 & 111.6 & NA & NA & Hassan et al. (2011) \\
\hline NA & 68.9 & NA & NA & NA & 2.3 & 3.4 & Loh et al. (2005) \\
\hline 470 & 74.0 & 513 & 420 & NA & NA & NA & $\begin{array}{l}\text { Martínez-Avalos } \\
\text { et al. (1998) }\end{array}$ \\
\hline 200 & 76.8 & 460 & 410 & 111.2 & NA & NA & $\begin{array}{l}\text { Lazcano et al. } \\
\text { (2008) }\end{array}$ \\
\hline
\end{tabular}

$D M$ Dry matter, $C P$ crude protein, $N D F$ neutral detergent fibre, $A D F$ acid detergent fibre, $T K$ total potassium, $T P$ total phosphorous, $N A$ not available 
this loses only about $52 \%$ of Nitrogen excreted by livestock is estimated to be recycled (Webb et al. 2012). In manure, Nitrogen is lost as ammonia or nitrous oxide. Ammonia volatilisation is the major pathway for Nitrogen loss (van der Meer 2008; Ndegwa et al. 2008). Emission occurs due to manure exposure to atmosphere in barns, during storage and application (Hafner et al. 2012).

\section{Composting and nitrogen lost}

The environmental and health risk imposed by ruminant manure mentioned earlier is due to its non stabilisation. Stabilisation is degree of decomposition of a waste substance, which is reflected by decrease in level of microbial biomass activity and concentrations of labile compounds (Benito et al. 2003). According to Lazcano et al. (2008), composting and vermicomposting are two of the best known processes for the biological stabilisation of solid waste. Composting is a well established method for stabilising and sterilising materials before returning them to agricultural land (Parkinson et al. 2004; Larney and Hao 2007). Composting is a continuous aerobic degradation of organic materials by microorganism into humus-like substances (Bernal et al. 2009; Peigne and Girardin 2004). Traditionally farmers carried out composting of animal manure for easy handling, transport and management. Composting technology provide a better option for manure treatment with economic and environmental benefits. Composting process results to decrease in volume and weight of the biomass, elimination or reduction of pathogens spreading, destruction of weeds and phytotoxicity, decreased in C:N ratio, odour free and easily spread products (Eghball and Lesoing 2000; Gómez-Brandón et al. 2008; Hristov et al. 2011; Larney et al. 2003; Larney and Hao 2007). Compared with application of fresh manure, compost application in the field reduces Nitrogen losses (Peigne and Girardin 2004). Composting of animal manure is a technology which adds value and produces a high quality product for multiple agricultural uses (Bernal et al. 2009); Table 2.

There are nutrients losses during composting and the loss can either be in form of gases, liquid (leachate) or both. The losses can result to environmental pollution. Nitrogen losses through composting can occur by ammonia volatilisation, leaching and denitrification, and through chemo-denitrification (Hao et al. 2001). Manure composting result in degradation of protein, urea or uric acid, and this produce ammonium due to Nitrogen transformation which involve several biochemical reactions (Peigne and Girardin 2004). The losses is high during the active phase of composting when the temperature is rising and decomposition is taking place and this
Table 2 Stages of composting process

\begin{tabular}{llll}
\hline Stage (phase) & $\begin{array}{l}\text { Micro-organism } \\
\text { involve }\end{array}$ & $\begin{array}{l}\text { Main bio- } \\
\text { chemical } \\
\text { reaction }\end{array}$ & $\begin{array}{l}\text { Gas } \\
\text { emission }\end{array}$ \\
\hline $\begin{array}{l}\text { Mesophilic } \\
\text { phase }\end{array}$ & $\begin{array}{c}\text { No specific micro- } \\
\text { organism: bacteria } \\
\text { dominant, } \\
\text { actinomycetes }\end{array}$ & Ammonification & - \\
$\begin{array}{c}\text { Thermophilic } \\
\text { phase }\end{array}$ & $\begin{array}{l}\text { Thermophilic } \\
\text { bacteria and fungi } \\
\text { dominant }\end{array}$ & Methanogenesis & Ammonia \\
& $\begin{array}{l}\text { Methanogen } \\
\text { thermophilic }\end{array}$ & Methane \\
& $\begin{array}{l}\text { bacteria } \\
\text { More specific } \\
\text { mesophilic micro- } \\
\text { phase }\end{array}$ & $\begin{array}{l}\text { Nitrification } \\
\text { Denitrification }\end{array}$ & $\begin{array}{c}\text { Nitrous } \\
\text { oxide }\end{array}$ \\
& $\begin{array}{l}\text { dominant, bacteria } \\
\text { actinomycetes and }\end{array}$ & & dioxide \\
& fungi & & \\
\hline
\end{tabular}

Adopted from Peigne and Girardin (2004) with modifications

indicate intense mineralisation (Bernal et al. 1996; Hao et al. 2011).

Total Nitrogen losses during composting can be up to $42 \%$ and related to the initial Nitrogen content in the manure (Eghball et al. 1997; Hao et al. 2004; GómezBrandón et al. 2008). Ammonia losses can account for about $92 \%$ and losses through leachate account for $<0.5 \%$ (Eghball et al. 1997). This depends on the initial manure mixture and compost management employed. Addition of condensed tannins in the diet of ruminant was found to increase the agronomic value of the compost without increased in greenhouse gas emission (Hao et al. 2011). Aeration or turning frequency also affect Nitrogen lost during composting (Hao et al. 2001; Parkinson et al. 2004). Mechanical turning increases greenhouse gas emission (Hao et al. 2001).

More than $95 \%$ of nitrous oxide is produced during the maturation phase of composting when readily available carbon sources has been depleted (He et al. 2001). Nutrients losses during composting are inevitable however nutrients in composted materials are less susceptible to leaching and volatilisation with advantage of suppressing pathogens and weed seed dispersal (Bernal et al. 2009), with ease of handling.

\section{Vermicomposting of ruminant manure and Nitrogen loss}

Composting reduces agronomic value of compost and contribute to greenhouse gas emission due to nutrients loss during compost making, in addition to energy loss due to labour or fuel required to turn the compost heap (Hao et al. 
2001). The process requires long time period to be completed and sometimes the products are heterogeneous (Ndegwa and Thompson 2001). Vermicomposting is a mesophilic bio-oxidation process of organic materials that involve the joint action of earthworm and microorganism. This increases the rate of the decomposition process by accelerating the stabilisation of organic matter and greatly modifying its physical and biochemical properties (Dominguez 2011). Microorganisms produce the enzymes that cause biochemical decomposition of organic matter, but earthworm are the crucial drivers as they stimulate and increase biological activity by fragmentation and ingestion of organic matter and this will increase the surface area to be exposed to microorganism (Dominguez 2011). They also serve as agent of turning and aeration (Ndegwa and Thompson 2001).

A Vermicomposting process has two distinguished phases and is (1) an active phase; where the earthworm process the biomass, modifying its physical state and microbial composition. The effect of earthworm on the decomposition of organic matter during vermicomposting processes is due to gut associated processes (GAPs), and it includes the modification that organic waste and microbes undergo during their passage through the gut of earthworm. (2) A maturation like phase; also known as cast associated processes (CAPs) is marked by the displacement of the earthworm towards fresher layers of undigested waste, where the microbes take over in the decomposition of waste and the effects of earthworm are mainly indirect and derived from GAPs (Dominguez and Edwards 2011; Dominguez 2011); Fig. 1.

Nutrients losses in biological processes are inevitable. Methane loss is negligible during vermicomposting as the process is aerobic and no methane was detected from earthworm or its gut content (Karsten and Drake 1997). (Velasco-Velasco et al. 2011), observed that high temperature and low moisture content during vermicomposting of sheep manure are responsible for ammonia emission, Nitrogen loss by ammonia volatilization during vermicomposting was up to $15 \%$ of the initial $\mathrm{N}$ content. A high nitrous oxide emission was reported by Frederickson and Howell (2003), during vermicomposting of organic waste, and this might be due to denitrification processes taking place within the guts of the earthworm. Earthworm guts are associated with denitrifying bacteria, these are responsible for nitrous oxide emission which can be up to $33 \%$ of the total nitrous oxide emission from the soil, and it increase with moistened of earthworm with nitrate and or nitrite (Matthies et al. 1999). The nitrous oxide emission is from earthworm under aerobic condition and from their guts under anaerobic condition (Karsten and Drake 1997). However, compared with composting, vermicomposting

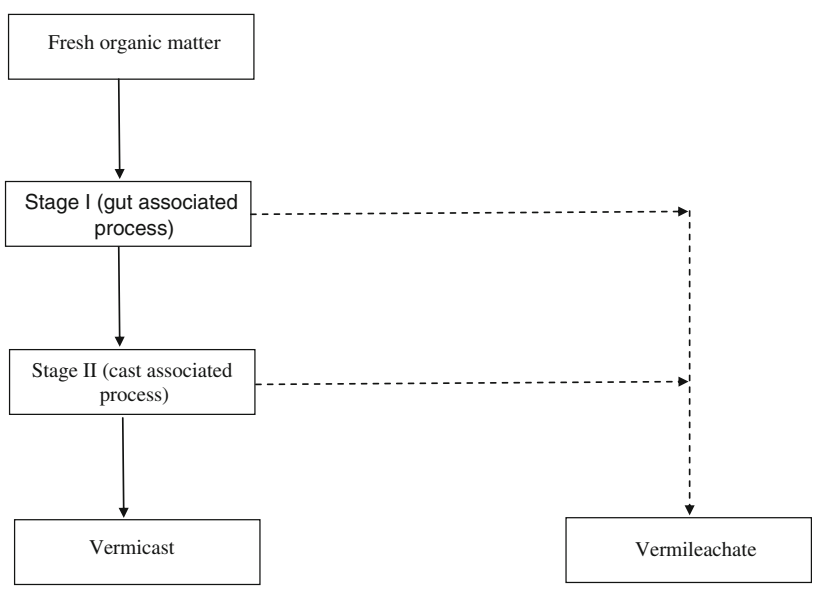

Fig. 1 Schematic stages in vermicomposting process

promote Nitrogen retention and produced more stabilised products (Frederickson et al. 2007; Lazcano et al. 2008).

Pre-treatment before vermicomposting was suggested by Nair et al. (2006), as waste may contain substances that might be toxic to earthworm such as acidic compound and gases emission. Kumar et al. (2010), pre-treated sugar cane waste by-products with microorganism before vermicomposting and it accelerated degradation and significantly reduced the time required for stabilisation. Frederickson et al. (2007) and Ndegwe and Thompson (2001), suggested pre-composting then followed by vermicomposting, composting eliminate toxic compounds, pathogens and weeds since it undergoes thermophilic phase where the temperature can be more than $55^{\circ} \mathrm{C}$ in contrast to vermicomposting which is mesophilic process where the temperature will not exceed $37^{\circ} \mathrm{C}$. However, Edwards and Subler (2011) reviewed literatures and stated that vermicomposting process eliminates or suppresses human pathogens. Lazcano et al. (2008), compared effectiveness of composting and vermicomposting for cattle manure stabilisation and found that pre-treatment with composting then followed with vermicomposting was the most effective in stabilising cattle manure. Vermicomposting is being used in ruminant manure stabilisation (Garg et al. 2006; Lazcano et al. 2008; Loh et al. 2005; Mitchell 1997; VelascoVelasco et al. 2011).

\section{Potentials of using vermicomposting products as feed supplement or probiotics to ruminant}

With increasing human population food shortages will become an ever increasing problem, unless agricultural output can keep pace with population growth. Animal products are crucial in this regards. Inadequate supply of good quality feed is the main factor hindering the 
progress of animal production in many developing countries. There, livestock depends on fibrous crop residues, which have low digestibility, low protein content, poor palatability and bulkiness (Zadrazil et al. 1995). Coupled with famine the said feed will not be available at that period. To enhance animal's performance the nutritional quality and palatability of fibrous crop residues have to be improved. This can be achieved by manipulating ruminal fermentation.

According to Wallace (1994), methods for manipulating ruminal fermentation that involve microbial biotechnology include dietary ionophores, antibiotics and microbial feed additives. For decades efforts have been put to produce ingredients for animal feedstuff from manure (Woesttyne and Verstrate 1995). To utilise cattle manure as feedstuff different processing methods (dehydration, compost silage, single cell protein production, pelleting, deep stacking, chemical preservation, and chemical enhancement of digestibility) have been employed (Bórquez et al. 2009; Sarwar et al. 2011). Usage of cattle manure as feedstuff in ruminant has the advantage of reducing pollution due to animal waste in addition to reducing feeding cost (Martínez-Avalos et al. 1998). However, some factors have affected efficient utilisation of cattle manure and these includes palatability, ease of handling, product quality and consumer acceptance (Bórquez et al. 2009). The method commonly used in treating cattle manure as feed resource is fermentation with soluble Nitrogen source such as urea and carbohydrate such as cane molasses through silage (Martínez-Avalos et al. 1998; Sarwar et al. 2006). Cattle manure was ensiled with urea/molasses/bakery by-product or corn stover treated straw with the aimed of improving feed quality. The results showed increased feed intake, nutrients digestibility, microbial protein supply and an increased in weight gain (Bórquez et al. 2009; Hassan et al. 2011; Martínez-Avalos et al. 1998; Sarwar et al. 2011). A cattle manure silage was used to replace concentrates (Bórquez et al. 2010). Up to $30 \%$ cattle manure inclusion in silage making was recommended for optimal utilisation in ruminant feeding.

Aerobic processes of pre-treating cattle manure with composting will ensure suppression of weed seeds and pathogens. The pre-treated manure can be vermicomposted with straws (forages) with the aims of improving its nutritive value. This will increases the Nitrogen content of the vermicomposted treated straws. As evidences shows that vermicomposting reduces $\mathrm{C}: \mathrm{N}$ ratio. This has the potential of feed supplement to ruminant. Vermicast can be a good source of Nitrogen to ruminant due its low $\mathrm{C}: \mathrm{N}$ ratio with likely low solubility in the rumen (Bernal et al. 1993). This might reduce Nitrogen losses in the rumen and overall Nitrogen losses due to ruminant production and increases Nitrogen retention. Results from cattle manure being ensiled with straws and other agro-by-products and fed to ruminants are encouraging; likewise the performance of the animals fed ensiled cattle manure. From these, cattle manure treated with pre-composting before vermicomposting with roughages or other agro-by-products might produce similar result or even better. This may be due increase in Nitrogen content of vermicomposting products, reduction of fibre content from forages as some cellulolytic activities was observed during vermicomposting. $\mathrm{pH}$ value of vermicast is within the neutral range in contrast with silage products which has a lower $\mathrm{pH}$ value due to increase of lactic acid during silage, this may reduce rumen $\mathrm{pH}$ thereby reducing microbial activities, in some cases high amount of lactic acid in the rumen may lead to sub acute ruminal acidosis (SARA). The inclusion of pre- composted cattle manure can be varied from 0 to $40 \%$ in order to ascertain the best level of inclusion for optimal performance.

\section{Conclusion}

Ruminant production is associated with Nitrogen loss especially in the form of ammonia from urine and manure management during composting. These contribute to greenhouse emission and environmental pollution in general. The most effective way to control and or minimise Nitrogen losses from ruminant production and their manure management is efficient strategic feeding that will provide the required nutrients without short or waste, in other words it should be through precision feeding. Precomposting followed by vermicomposting provides an effective way of ruminant manure management. Vermicast a product of vermicomposting is a good soil fertiliser which has the potential of being feed supplement to ruminant. This can be achieved by pre composting of cattle manure and then vermicompost with forages. The inclusion of pre-composted cattle manure can be varied from 0 to $40 \%$ in order to ascertain the best level of inclusion for optimal performance. Fibrous crop residues are ruminant feed available in developing countries in some month of the year. Therefore this potentiality should be explored with the aim of reducing environmental pollution from ruminant production and providing nutritional benefit to ruminant from their manure management. Pre-composting of ruminant manure and its subsequent vermicomposting provide a potential of feed supplement and probiotics to ruminant.

Acknowledgments The first author acknowledges USM-TWAS PG fellowship 2010 for fellowship award. The study was funded through Universiti Sains Malaysia (USM) grant (Grant No: 304/PTEKIND/ 650428). The authors acknowledge USM for providing research facilities. 
Authors' contributions AN: Collected and reviewed the literature and drafted the manuscript. MHI and NI: Formulated the objectives, provided guidance and improved the quality of the manuscript. All authors read and approved the final manuscript.

Open Access This article is distributed under the terms of the Creative Commons Attribution License which permits any use, distribution, and reproduction in any medium, provided the original author(s) and the source are credited.

\section{References}

Alvarez R, Lidén G (2009) Low temperature anaerobic digestion of mixtures of llama, cow and sheep manure for improved methane production. Biomass Bioenergy 33(3):527-533. doi:10.1016/j. biombioe.2008.08.012

Amon T, Amon B, Kryvoruchko V, Zollitsch W, Mayer K, Gruber L (2007) Biogas production from maize and dairy cattle manureinfluence of biomass composition on the methane yield. Agric Ecosyst Environ 118(1-4):173-182. doi:10.1016/j.agee.2006.05. 007

Benito M, Masaguer A, Moliner A, Arrigo N, Palma RM (2003) Chemical and microbiological parameters for the characterisation of the stability and maturity of pruning waste compost. Biol Fertil Soils 37(3):184-189. doi:10.1007/s00374-003-0584-7

Bernal MP, Lopez-Real JM, Scott KM (1993) Application of natural zeolites for the reduction of ammonia emissions during the composting of organic wastes in a laboratory composting simulator. Biores Technol 43(1):35-39. doi:10.1016/09608524(93)90079-q

Bernal MP, Navarro AF, Roig A, Cegarra J, García D (1996) Carbon and nitrogen transformation during composting of sweet sorghum bagasse. Biol Fertil Soils 22(1):141-148. doi:10.1007/ bf00384446

Bernal MP, Alburquerque JA, Moral R (2009) Composting of animal manures and chemical criteria for compost maturity assessment. A review. Biores Technol 100(22):5444-5453. doi:10.1016/j. biortech.2008.11.027

Bórquez JL, González-Muñoz SS, Pinos-Rodríguez JM, Domínguez I, Bárcena JR, Mendoza GD, Cobos MA, Bueno G (2009) Feeding value of ensiling fresh cattle manure with molasses or bakery byproducts in lambs. Livest Sci 122(2-3):276-280. doi:10.1016/j. livsci.2008.09.009

Bórquez JL, Pinos-Rodríguez JM, González SS, Domínguez I, Bárcena R, Mendoza G, Cobos M (2010) Use of different kind of silage dairy cattle manure in lamb nutrition. Ital J Anim Sci 9(1)

Dijkstra J, France J, Ellis JL, Kebreab E, López S, Reijs JW, Bannink A (2011a) Effects of nutritional strategies on simulated nitrogen excretion and methane emission in dairy cattle. In: Sauvant D, Milgen JV, Faverdin P, Friggens N (eds) Modelling nutrient digestion and utilisation in farm animals. Wageningen Academic Publishers, The Netherlands

Dijkstra J, Oenema O, Bannink A (2011b) Dietary strategies to reducing $\mathrm{N}$ excretion from cattle: implications for methane emissions. Curr Opin Environ Sustainabil 3(5):414-422. doi:10. 1016/j.cosust.2011.07.008

Dominguez J (2011) The microbiology of vermicomposting. In: Edwards CA, Arancon NQ, Sherman R (eds) Vermiculture technology earthworms, organic wastes, and environmental management. CRC Press, Boca Raton, pp 53-66

Dominguez J, Edwards CA (2011) Relationships between composting and vermicomposting. In: Edwards CA, Arancon NQ, Sherman R (eds) Vermiculture technology earthworms, organic wastes, and environmental management. CRC Press, Boca Raton, pp 11-26
Edwards CA, Subler S (2011) Human pathogen reduction during vermicomposting. In: Edwards CA, Arancon NQ, Sherman R (eds) Vermiculture technology earthworms, organic wastes, and environmental management. CRC Press, Boca Raton, pp 249-262

Eghball B, Lesoing GW (2000) Viability of weed seeds following manure windrow composting. Compost Sci Utilization 8(1):46-53

Eghball B, Power JF, Gilley JE, Doran JW (1997) Nutrient, carbon, and mass loss during composting of beef cattle feedlot manure. J Environ Qual 26(1):189-193. doi:10.2134/jeq1997. $00472425002600010027 \mathrm{x}$

Frederickson J, Howell G (2003) Large-scale vermicomposting: emission of nitrous oxide and effects of temperature on earthworm populations: the 7th international symposium on earthworm ecology · Cardiff . Wales · 2002. Pedobiologia 47(5-6):724-730. doi:10.1078/0031-4056-00250

Frederickson J, Howell G, Hobson AM (2007) Effect of precomposting and vermicomposting on compost characteristics. Eur J Soil Biol 43(Suppl 1):S320-S326. doi:10.1016/j.ejsobi. 2007.08.032

Garg V, Yadav Y, Sheoran A, Chand S, Kaushik P (2006) Livestock excreta management through vermicomposting using an epigeic earthworm Eisenia foetida. Environmentalist 26(4):269-276. doi:10.1007/s10669-006-8641-z

Gómez-Brandón M, Lazcano C, Domínguez J (2008) The evaluation of stability and maturity during the composting of cattle manure. Chemosphere 70(3):436-444. doi:10.1016/j.chemosphere.2007. 06.065

Gutiérrez-Miceli FA, Moguel-Zamudio B, Abud-Archila M, Gutiérrez-Oliva VF, Dendooven L (2008) Sheep manure vermicompost supplemented with a native diazotrophic bacteria and mycorrhizas for maize cultivation. Biores Technol 99(15):7020-7026. doi:10.1016/j.biortech.2008.01.012

Hafner SD, Montes F, Alan Rotz C (2012) The role of carbon dioxide in emission of ammonia from manure. Atmos Environ. doi:10. 1016/j.atmosenv.2012.01.026

Hao X, Chang C, Larney FJ, Travis GR (2001) Greenhouse gas emissions during cattle feedlot manure composting. J Environ Qual 30(2):376-386. doi:10.2134/jeq2001.302376x

Hao X, Chang C, Larney FJ (2004) Carbon, nitrogen balances and greenhouse gas emission during cattle feedlot manure composting. J Environ Qual 33(1):37-44. doi:10.2134/jeq2004.3700

Hao X, Benke MB, Li C, Larney FJ, Beauchemin KA, McAllister TA (2011) Nitrogen transformations and greenhouse gas emissions during composting of manure from cattle fed diets containing corn dried distillers grains with solubles and condensed tannins. Anim Feed Sci Technol 166-167:539-549. doi:10.1016/j. anifeedsci.2011.04.038

Hassan Z, Nisa M, Shahzad M, Sarwar M (2011) Replacing concentrate with wheat straw treated with urea molasses and ensiled with manure: effects on ruminal characteristics, in situ digestion kinetics and nitrogen metabolism of Nili-Ravi buffalo bulls. Asian Austral J Anim Sci 24(8):1092-1099

He Y, Inamori Y, Mizuochi M, Kong H, Iwami N, Sun T (2001) Nitrous oxide emissions from aerated composting of organic waste. Environ Sci Technol 35(11):2347-2351. doi:10.1021/es0011616

Hristov AN, Jouany JP (2005) Factors affecting the efficiency of nitrogen utilization in the rumen. In: Pfeffer E, Hristov AN (eds) Nitrogen and phosphorus nutrition of cattle reducing the environmental impact of cattle operations. CABI Publishing, Cambridge

Hristov AN, Hanigan M, Cole A, Todd R, McAllister TA, Ndegwa PM, Rotz A (2011) Review: ammonia emissions from dairy farms and beef feedlots 1. Canadian J Anim Sci 91(1):1-35. doi:10.4141/cjas 10034

IPCC (2007) Climate Change 2007: Impacts, Adaptation and Vulnerability. Summary for policy makers (Intergovernmental Panel on Climate Change) 
Karsten GR, Drake HL (1997) Denitrifying bacteria in the earthworm gastrointestinal tract and the in vivo emission of nitrous oxide $\left(\mathrm{N}_{2} \mathrm{O}\right)$ by earthworms. Appl Environ Microbiol 63:1878-1882 citeulike-article-id:6224365

Kulling DR, Menzi H, Krober TF, Neftel A, Sutter F, Lischer P, Kreuzer M (2001) Emissions of ammonia, nitrous oxide and methane from different types of dairy manure during storage as affected by dietary protein content. J Agric Sci 137(02):235-250. doi: $10.1017 /$ S0021859601001186

Kumar R, Verma D, Singh BL, Kumar U, Shweta (2010) Composting of sugar-cane waste by-products through treatment with microorganisms and subsequent vermicomposting. Biores Technol 101(17):6707-6711. doi:10.1016/j.biortech.2010.03.111

Larney FJ, Hao X (2007) A review of composting as a management alternative for beef cattle feedlot manure in southern Alberta, Canada. Biores Technol 98(17):3221-3227. doi:10.1016/j.bior tech.2006.07.005

Larney FJ, Yanke LJ, Miller JJ, McAllister TA (2003) Fate of coliform bacteria in composted beef cattle feedlot manure. J Environ Qual 32(4):1508-1515. doi:10.2134/jeq2003.1508

Lazcano C, Gómez-Brandón M, Domínguez J (2008) Comparison of the effectiveness of composting and vermicomposting for the biological stabilization of cattle manure. Chemosphere 72(7):1013-1019. doi:10.1016/j.chemosphere.2008.04.016

Loh TC, Lee YC, Liang JB, Tan D (2005) Vermicomposting of cattle and goat manures by Eisenia foetida and their growth and reproduction performance. Biores Technol 96(1):111-114. doi:10.1016/j.biortech.2003.03.001

Martínez-Avalos AMM, Mendoza GD, Cobos MA, González S, García-Bojalil CM, Bárcena R (1998) Nutritional evaluation of cattle manure silage with molasses for ruminants. Anim Feed Sci Technol 70(3):257-264. doi:10.1016/s0377-8401(97)00007-2

Massé DI, Talbot G, Gilbert Y (2011) On farm biogas production: a method to reduce GHG emissions and develop more sustainable livestock operations. Anim Feed Sci Technol 166-167:436-445. doi:10.1016/j.anifeedsci.2011.04.075

Mathot M, Decruyenaere V, Stilmant D, Lambert R (2012) Effect of cattle diet and manure storage conditions on carbon dioxide, methane and nitrous oxide emissions from tie-stall barns and stored solid manure. Agric Ecosyst Environ 148:134-144. doi:10.1016/j.agee.2011.11.012

Matthies C, Grießhammer A, Schmittroth M, Drake HL (1999) Evidence for involvement of gut-associated denitrifying bacteria in emission of nitrous oxide $\left(\mathrm{N}_{2} \mathrm{O}\right)$ by earthworms obtained from garden and forest soils. Appl Environ Microbiol 65(8):3599-3604

Mitchell A (1997) Production of Eisenia foetida and vermicompost from feed-lot cattle manure. Soil Biol Biochem 29(3-4):763-766. doi:10.1016/s0038-0717(96)00022-3

Nair J, Sekiozoic V, Anda M (2006) Effect of pre-composting on vermicomposting of kitchen waste. Biores Technol 97(16):2091-2095. doi:10.1016/j.biortech.2005.09.020

Ndegwa PM, Thompson SA (2001) Integrating composting and vermicomposting in the treatment and bioconversion of biosolids. Biores Technol 76(2):107-112. doi:10.1016/s0960-8524(00)00104-8

Ndegwa PM, Hristov AN, Arogo J, Sheffield RE (2008) A review of ammonia emission mitigation techniques for concentrated animal feeding operations. Biosyst Eng 100(4):453-469. doi:10. 1016/j.biosystemseng.2008.05.010

O'Mara FP (2011) The significance of livestock as a contributor to global greenhouse gas emissions today and in the near future. Anim Feed Sci Technol 166-167:7-15. doi:10.1016/j.anifeedsci. 2011.04.074

Oenema O (2006) Nitrogen budgets and losses in livestock systems. Int Congr Ser 1293:262-271. doi:10.1016/j.ics.2006.02.040

Parkinson R, Gibbs P, Burchett S, Misselbrook T (2004) Effect of turning regime and seasonal weather conditions on nitrogen and phosphorus losses during aerobic composting of cattle manure. Biores Technol 91(2):171-178. doi:10.1016/s0960-8524(03)00174-3

Patra AK, Saxena J (2011) Exploitation of dietary tannins to improve rumen metabolism and ruminant nutrition. J Sci Food Agric 91(1):24-37. doi:10.1002/jsfa.4152

Peigne J, Girardin P (2004) Environmental impacts of farm-scale composting practices. Water Air Soil Pollut 153:45-68

Powell JM, Ikpe FN, Somda ZC (1999) Crop yield and the fate of Nitrogen and phosphorus following application of plant material and feces to soil. Nutr Cycl Agroecosyst 54(3):215-226. doi:10. 1023/a:1009762900258

Powell JM, Broderick GA, Grabber JH, Hymes-Fecht UC (2009) Technical note: effects of forage protein-binding polyphenols on chemistry of dairy excreta. J Dairy Sci 92(4):1765-1769. doi:10. 3168/jds.2008-1738

Sarwar M, Nisa M, Hassan Z, Shahzad MA (2006) Influence of urea molasses treated wheat straw fermented with cattle manure on chemical composition and feeding value for growing buffalo calves. Livest Sci 105(1-3):151-161. doi:10.1016/j.livsci.2006. 05.021

Sarwar M, Shahzad M, Nisa M, Afzal D, Sharif M, Saddiqi H (2011) Feeding value of urea molasses-treated wheat straw ensiled with fresh cattle manure for growing crossbred cattle calves. Trop Anim Health Prod 43(3):543-548. doi:10.1007/s11250-0109745-5

Sommer SG, Hutchings NJ (2001) Ammonia emission from field applied manure and its reduction-invited paper. Eur J Agron 15(1):1-15. doi:10.1016/s1161-0301(01)00112-5

Tamminga S (1992) Nutrition management of dairy cows as a contribution to pollution control. J Dairy Sci 75(1):345-357. doi:10.3168/jds.S0022-0302(92)77770-4

Tamminga S (2003) Pollution due to nutrient losses and its control in European animal production. Livest Prod Sci 84(2):101-111. doi:10.1016/j.livprodsci.2003.09.008

van der Meer HG (2008) Optimising manure management for GHG outcomes. Aust J Exp Agric 48(2):38-45

van der Stelt B, van Vliet PCJ, Reijs JW, Temminghoff EJM, van Riemsdijk WH (2008) Effects of dietary protein and energy levels on cow manure excretion and ammonia volatilization. J Dairy Sci 91(12):4811-4821

van Vliet PCJ, Reijs JW, Bloem J, Dijkstra J, de Goede RGM (2007) Effects of cow diet on the microbial community and organic matter and nitrogen content of feces. J Dairy Sci 90(11):5146-5158. doi:10.3168/jds.2007-0065

Velasco-Velasco J, Parkinson R, Kuri V (2011) Ammonia emissions during vermicomposting of sheep manure. Biores Technol 102(23):10959-10964. doi:10.1016/j.biortech.2011.09.047

Waghorn G (2008) Beneficial and detrimental effects of dietary condensed tannins for sustainable sheep and goat productionprogress and challenges. Anim Feed Sci Technol 147(1-3):116-139. doi:10.1016/j.anifeedsci.2007.09.013

Wallace RJ (1994) Ruminal microbiology, biotechnology, and ruminant nutrition: progress and problems. J Anim Sci 72:2992-3003

Webb J, Sommer SG, Kupper T, Groenestein K, Hutchings NJ, Eurich-Menden B, Rodhe L, Misselbrook TH, Amon B (2012) Emissions of ammonia, nitrous oxide and methane during the management of solid manures. Sustain Agr Rev 8:67-107

Woesttyne MV, Verstrate W (1995) Biotechnology in the treatment of animal manure. In: Biotechnology in animal feeds and animal feeding. Wiley-VCH Verlag GmbH, pp 311-327. doi:10.1002/ 9783527615353.ch16

Zadrazil F, Puniya AK, Singh K (1995) Biological upgrading of feed and feed components. In: Biotechnology in animal feeds and animal feeding. Wiley-VCH Verlag $\mathrm{GmbH}$, pp 55-70. doi:10. 1002/9783527615353.ch4 